\title{
Smartphone usage on senior citizen
}

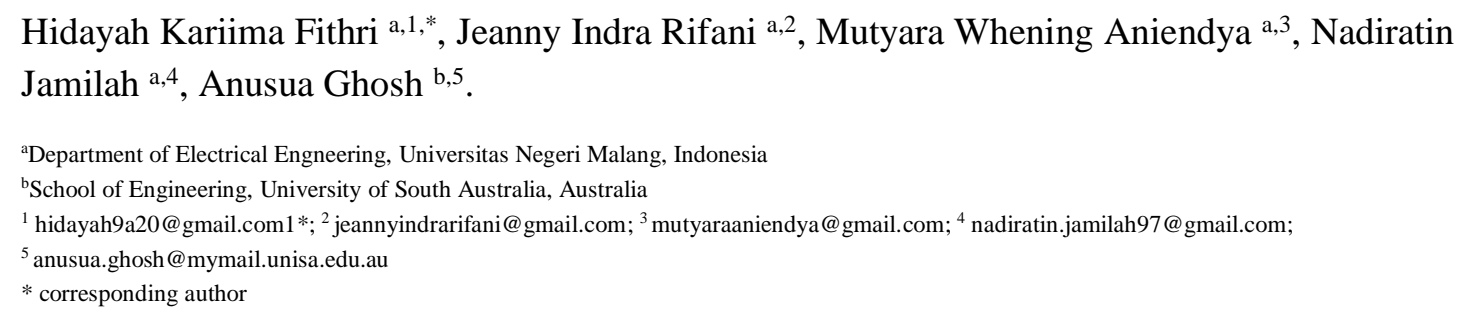

Article history

Received December 21, 2019

Revised January 14, 2020

Accepted February 1, 2020
The impact of the digital era is the gap between active smartphone users and those who are not particular. Then IT is not fully felt by the senior citizen. This study aims to determine the ability of the senior citizen in the use of smartphones. The results of the study will be used as a reference for teaching IT to four senior citizen people. As a result, two senior citizen people want to be taught to use smartphones intensive and privately.
Keywords

Smartphone

Usage

Senior Citizen
This is an open access article under the CC-BY-SA license.

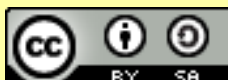

\section{Introduction}

The development of technology makes it easy for humans to complete work but the introduction of technology is only done to children and adults. This results in a gap of the senior citizen or those over the age of 60 years [1]. Decreasing physical conditions, reduced income, limited relationships threaten the existence and happiness of the elderly, causing the senior citizento feel left behind because the world seems to be faster with technology even though the senior citizen need to stay connected with technology. The technology that is developing at this time and much in demand is a smartphone [2].

Smartphones have advantages such as functions to take photos, play songs, record sound and access geographic information and the global positioning system (GPS) [3]. Now there are many people who use smartphones that have internet connections with touch screens [4]. In other words, smartphones can be categorized as mini-computers that have many functions and have high mobility [3], [5]. Many reasons people use smartphones, teenagers are more focused on social media for the purpose of communicating this goal is certainly different from the elderly [6], [7].

Previously there was research conducted in Japan [8] the results of the study were the idea of a method called RemoSupp for the senior citizento teach and support the senior citizenfor internet technology conducted by Japanese IT volunteers. The research will be adopted in this paper for research with cases of the senior citizenin Malang. The aim is to determine the ability of the senior citizento operate a smartphone and determine the suitable method used to teach the operation of smartphones in a sample of four senior citizenpeople in Malang City. The approaches and preferences for learning technology vary at various ages. Older adults prefer learning through printed instruction manuals, compared to their younger counterparts who prefer the trial-and-error method [9]. The results of this study provide an effort to reduce the digital divide due to age factors so that an effective method is needed to introduce IT with smartphones to the senior citizen. 


\section{Method}

\subsection{Analysis of the Current System}

Previous research conducted by Wei Zhou and Shigekei Yokoi used the remote method, where the senior citizen can learn about IT guided by volunteers [8]. This remote method allows volunteers to overcome the constraints of the difference in distance they have. This method provides benefits not only in terms of transportation costs to approach the senior citizen in learning, but this method also indirectly makes the senior citizen can apply remote technology to learn about the internet and solutions to overcome trouble shooting.

In contrast to the research previously outlined briefly, the research we conducted took a simpler sample by taking data by conducting random interviews in the elderly. The target of our respondents comes from different social levels, education levels and employment status in Indonesian society, especially in Malang City.

The interview method is chosen because it is a flexible method. This method has its own advantages for us, where respondents are far more open and comfortable with us in conveying what is known, seen, felt, and expected.

The environment in Japan (referring to previous research) is very different from Indonesia. The hypothesis that we have based on the existence of environmental differences is that not all people in Indonesia can operate a smartphone. There are social factors, economic factors, and educational factors that influence. The following is an explanation of each factor we consider:

\section{1) Economical Factor}

The essence of the economic problem faced by humans is the fact that human needs are unlimited [10], while the means of satisfying human needs are limited. This research is closely related to the problems raised in this study, because economic factors can influence social status in society.

According to data from Newzoo's Global Mobile Market Report in 2018, it was noted that Indonesia at $25.4 \%$ was smartphone penetration and as many as 67,570,000 were smartphone users [11]. This means that Indonesia's ranking in smartphone usage is still low.

\section{2) Social Humanity Factor}

In this study, this factor leads to public relations which are about strata. This strata is formed because of the economic factors that influence. Senior citizen in the upper strata, certainly know the appearance of smartphones and their functions, while those in the middle to lower strata, not many of those who understand smartphones don't even know the form of a smartphone.

\section{3) Educational Factor}

Regarding economic factors and social factors, educational factors also influence [12], [13]. Generally, the people (elderly) who really don't know smartphones are people who lived in the era before smartphones existed, so education did not introduce the form and function of smartphones.

For the senior citizens who are still productive, such as lecturers at educational institutions, they certainly know smartphones because they teach the younger generation who know the shape and function of smartphones. So that the productive lecturers are forced to study smartphones to provide information online and search for academic data.

\subsection{Data Collection}

The data we obtain is the result of interviews with four respondents; two of them came from Malang City, and the rest came from Malang Regency. The interview process that we did was to invite the respondents to speak as comfortable as possible, but we still have the variable questions that became our topic. Table 1 shows are our main variables.

Based on the variables we use, this variable is able to extract information from respondents. The concept of our first interview is to explore the background of the respondents, the second is to explore information about whether the respondents have used smartphones or ordinary mobile phones and the length of ownership of their cellphones or smartphones, and thirdly we will ask respondents to test our ability. This ability test is done to see the ability as well as to find out whether age, education status, and employment status can influence the interest in using a smartphone. 
Table 1. Variable Data

\begin{tabular}{cc}
\hline Variable & Description \\
\hline Region (City / Regency) & To find out whether the skills of the City community are superior or equal to the \\
Regency community & Between 55-80 years old \\
Age & To find out the effect of work status in smartphone usage \\
Education Status & To find out the influence of the latest educational status in smartphone use \\
To find out about the interest in using a smartphone
\end{tabular}

\subsection{Data Processing}

Data processing is the stage of the process after the data is obtained. This stage aims to get analysis and conclusions from the research conducted. The data in the form of videos that we produce will be transcribed in advance to merge data from four respondents. The results of this transcript will further facilitate the data analysis process.

\section{Result and Discussions}

The results of the interviews and the data processing phase that we did, we got some data and influencing factors and factors that did not influence. Next we describe the results of the interviews conducted. Table 1 shows the data that obtained from the interview.

Based on the results of this study, there were one person who could not use a hand phone/smartphone, three people who could use hand phone/smartphone but couldn't use the internet, and no one who could use the internet.

Table II. Obtained Data

\begin{tabular}{|c|c|c|c|c|}
\hline Statement & $\mathbf{A}$ & B & C & D \\
\hline Age & 70 y.o & 72 у.о & 70 у.о & 73 у.о \\
\hline Job Status & Housewife & Pensionary & Pensionary & Pensionary \\
\hline Education Statis & Elementary School & S1 & & Senior High School \\
\hline Ownership of HP & Yes & No & No & Yes \\
\hline $\begin{array}{l}\text { Ownership of } \\
\text { Smartphone }\end{array}$ & No & Yes & No & No \\
\hline $\begin{array}{l}\text { Time Periode } \\
\text { using HP }\end{array}$ & 5 years & - & - & 10 years \\
\hline $\begin{array}{l}\text { Time Periode } \\
\text { using Smatphone }\end{array}$ & - & 2 years & - & - \\
\hline Skill I & $\begin{array}{l}\text { Only accept incoming } \\
\text { calls }\end{array}$ & $\begin{array}{l}\text { Receive and call, play } \\
\text { music from playlists, } \\
\text { take photos }\end{array}$ & - & SMS, Receive and call \\
\hline Skill II & $\begin{array}{c}\text { Open Google and type } \\
\text { on the QWERTY } \\
\text { keyboard }\end{array}$ & - & $\begin{array}{l}\text { Introduce } \\
\text { smartphone } \\
\text { features }\end{array}$ & $\begin{array}{c}\text { Open Google and type } \\
\text { on the QWERTY } \\
\text { keyboard }\end{array}$ \\
\hline Length of Study & 45 minute & - & 10 minute & 15 minute \\
\hline $\begin{array}{l}\text { Interest with } \\
\text { smartphone }\end{array}$ & Interest & Not Interest & Interest & Interest \\
\hline Reason & $\begin{array}{c}\text { Tired of seeing the } \\
\text { news on TV }\end{array}$ & - & Easier in use & Faster in use \\
\hline
\end{tabular}


For respondent A, she was very interested in smartphones even though his last education was elementary school. For respondent A, he was very interested in smartphones even though his last education was elementary school. After the interviewer did a demo about searching for information on Google, the respondents were able to conclude why so many people use smartphones. When starting to learn on the QWERTY keyboard, respondents felt very difficult because previously they were only able to receiving calls on operating their hand phone. When information has been found, respondent a still does not know that the information has been displayed, from that the interviewer concludes that more than 1 learning process is needed

For respondent B, she already has a smartphone and she knowing how to do some work on a smartphone such as calling and receiving phone calls, listening to murottal (reciting Al-Quran) from the application and taking photos through an existing camera on that smartphone. But respondents $\mathrm{B}$ are not interested in learning anything else that possible to do on smartphone, because he felt it was enough by the features he usually used on smartphone.

For respondents $\mathrm{C}$, she did not have a hand phone or smartphone, but because of the supportive environment of almost all children and grandchildren having smartphones, he was very interested in learning how to operate and use a smartphone[14]. Respondents use smartphones to call through the Whatsapp Messenger application but this is still aided by their children and grandchildren. Respondents were also very enthusiastic when taught new things related to smartphones.

For respondent $\mathrm{D}$, he has a hand phone and is interested in learning how to operate and use a smartphone. After the interviewer did a demo about browsing on Google, the respondent immediately knew when there was a new page that appeared on the smartphone screen, and then the interviewer told to the respondent to do the activity himself. When introduced on the QWERTY keyboard, there were no obstacles it is just to use it takes a long time because looking for letters that are separate and he previously typed using the abc-def keyboard not QWERTY keyboard. Respondents are very interested in learning anything else that possible to do on smartphone and he are interested to buy own smartphones because he felt that having a smartphone would be easier and faster to obtain information or do a job

\section{Conclusion}

Technology learning is only focused on children and adults. So that active smartphone users who are able to operate their features properly start from the age of junior high school to adulthood. Even though the senior citizen also need knowledge about the use and use of tools as a result of technological developments such as smartphones, given the many benefits that can be obtained from the sophistication of smartphones. Although many factors influence whether a senior citizen person wants to learn about technological developments, especially the operation of a smartphone or not.

Based on the results of the research that has been carried out there are three variations of grouping in the understanding of the senior citizen towards the operation of the smartphone which consists of good, the senior citizen can operate the smartphone and use its features as needed, medium, the senior citizen can know the smartphone features but have difficulty operating the smartphone and bad, the senior citizen cannot use smartphones at all. An effective method for teaching the operation of smartphones in the senior citizen is face to face, private with intensive guidance.

\section{Reference}

[1] W. Zhou, T. Yasuda, and S. Yokoi, “An IT Social Support Environment for Senior Beginners," IPSJ SIG Tech. Rep., vol. 3, no. 16, pp. 9-15, 2006.

[2] M. Sharples and D. Spikol, "Mobile Learning," in Technology Enhanced Learning: Research Themes, E. Duval, M. Sharples, and R. Sutherland, Eds. Cham: Springer International Publishing, 2017, pp. 89-96.

[3] M. Salehan and A. Negahban, "Social networking on smartphones: When mobile phones become addictive," Comput. Human Behav., vol. 29, no. 6, pp. 2632-2639, 2013.

[4] K. Dehnen-Schmutz, G. L. Foster, L. Owen, and S. Persello, "Exploring the role of smartphone technology for citizen science in agriculture," Agron. Sustain. Dev., vol. 36, no. 2, p. 25, 2016. 
[5] Y. T. Sung, K. E. Chang, and T. C. Liu, "The effects of integrating mobile devices with teaching and learning on students' learning performance: A meta-analysis and research synthesis. Computers \& Education, 94, 252-275.," A meta-analysis Res. Synth. Comput. Educ., vol. 94, pp. 252-275, 2016.

[6] J. Mastrodicasa and P. Metellus, “The Impact of Social Media on College Students," J. Coll. Character, vol. 14, no. 1, pp. 21-30, 2013.

[7] H. T. Chen and X. Li, "The contribution of mobile social media to social capital and psychological wellbeing: Examining the role of communicative use, friending and self-disclosure," Comput. Human Behav., vol. 75, pp. 958-965, 2017.

[8] W. Zhou and S. Yokoi, "A Study of Remote Support by IT Volunteer Group for Senior Citizens," J. Socio-Informatics, vol. 2, no. 1, pp. 103-113, 2009.

[9] H. M. Mohadisdudis and N. M. Ali, "A Study of Smartphone Usage and Barriers Among the Elderly," in 2014 3rd International Conference on User Science and Engineering (i-USEr), 2014, pp. 109-114.

[10] W. J. Fellner and B. Goehmann, "Human needs, consumerism and welfare," Cambridge J. Econ., vol. 44, no. 2, pp. 303-318, 2020.

[11]Newzoo, “2018 Global Digital,” pp. 1-25, 2018.

[12] M. Zhitomirsky-Geffet and M. Blau, "Cross-generational analysis of predictive factors of addictive behavior in smartphone usage," Comput. Human Behav., vol. 64, pp. 682-693, 2016.

[13]H. S. Al-Barashdi, A. Bouazza, and N. H. Jabur, "Smartphone addiction among university undergraduates: a literature review," J. Sci. Res. Reports, vol. 4, no. 3, pp. 210-225, 2015.

[14] M. J. R. Priyani, "Lansia yang bahagia di era internet," in Prosiding Temu Ilmiah Nasional X Ikatan Psikologi Perkembangan Indonesia 1, 2017, pp. 299-306. 